Nikolaeva Lyudmila, $\mathrm{PhD}$ (Law Sciences), Associate Professor, Kyiv National University of Trade and Economics, 19, Kyoto str., Kyiv, 02156, Ukraine ORCID: 0000-0003-4710-0386

Harat Mikhailo, Postgraduate Student, Kyiv National University of Trade and Economics, 19, Kyoto str., Kyiv, 02156, Ukraine ORCID: 0000-0002-4293-3322

\title{
LEGAL BASE DEVELOPMENT OF BUILDING INDUSTRY IN INDEPENDENT UKRAINE
}

The article covers the issues related to the genesis of the legal framework of the building industry within formation of independent Ukraine until today. It was carried out the analysis of the legislation that used to regulate and regulates building activity in the relevant periods of building industry development. There are investigated and revealed the contents of these periods and their peculiarities. The basic tendencies of genesis of the building legislation in the modern period are researched.

Key words: building industry, development, legislation, building activity.

Ніколаєва Людмила, Гарат Михайло. Розвиток правової бази будівельної галузі в Незалежній Украӥні.

У статті висвітлюються питання генезису законодавчої бази будівельної галузі в умовах становлення незалежної України до наших днів. Був проведений аналіз законодавства, яке застосовувалося для регулювання та регулювання будівельної діяльності у відповідні періоди розвитку будівельної галузі. Визначено $і$ розкрито зміст иих періодів та їх особливості. Досліджено основні тендениії вдосконалення будівельного законодавства в сучасний період.

Ключові слова: будівельна галузь, розвиток, законодавство, будівельна діяльність.

Relevance of research topic. The genesis of the legal regulation of the building industry is a complex and important process which should be considered both in legal and historical terms. Building legislation is constantly dynamic and has being improved. Within the period of independence of Ukraine the evolution of social, political and economic processes led to the emergence and formation of new forms of legal regulation in the building sphere. 
A critical study of the historical experience of regulatory regulation in the area of planning and development of territories contributes to the better understanding of the positive and negative aspects of modern construction legislation. The genesis of the administrative and legal regulation of the planning and development of territories within independence of Ukraine is still underdeveloped in the administrative doctrine.

When independence of Ukraine was declared, legal regulation of the building industry was carried out on the basis of a large number of technical norms of the Soviet Union. In general, as of 1991, the state had a complex system of standardization and regulation in the building industry, and the young state was tasked with updating morally outdated regulations.

Analysis of recent research and publications. Considering its relevance, the topic of development of the building industry legal framework became the object of scientific research of N. Gushtik, O. Kvasnitska, T.Kolomoets, N. Mel'nka, M. Lavrentyev, V. Olyukh, V. Revenko, I. Tarasenko, V. Cherep, O. Yankovska and others. However, a thorough study of the development of the building industry legal framework in independent Ukraine was not conducted, which makes the relevance of such research.

The purpose of the article is to determine the periodization of the building legislation developmen, to identify the characteristic features in each individual period, to analyze the current state of the construction legislation and to formulate proposals for its improvement.

Presenting main material. The first stage in the development of administrative regulation of the building industry in independent Ukraine is the 16-year period from 1991 to 2007 which is characterized by the formation of fundamental legal documents that have determined the genesis of the legal regulation in the future.

Law of Ukraine «On the Basics of Urban Planning is one of the first significant legal act of independent Ukraine» (7), which was adopted in 1992 and regulates the construction industry. It defined the legal, economic, social and organizational principles of urban development. The Law establishes basic requirements for urban development and regulates land relations in urban development. One of the main provisions of this Law was definition of the main directions of building activity regulation and the competence of the authorities in the sphere of urban development.

Another important legislative act on regulation of building industry was the Law of Ukraine «On the Responsibility of Enterprises, their Associations, Institutions and Organizations for Offenses in the Sphere of Urban Development» (10) dated 14.10.1994. According to the Law, the officials of the State Architectural and Construction Control Inspectorates were entitled to provide relevant authorities by proposals for cancellation or suspension of licenses for certain works on design and construction and to suspend construction works.

A major step forward was the adoption of the Law of Ukraine «On Planning and Development of Territories dated» (8) 20.04.2000. The Law obliged the 
developers to obtain the necessary permission for the construction of urban development objects and the permission for construction works, which testified their right to take appropriate actions, connection of the construction object to utilities and structures, issue of warrants for land works.

The adoption of the Law of Ukraine «On the General Scheme of Planning of the Territory of Ukraine» (6) dated 07.02.2002 has made a significant impact on the sphere of administrative regulation of building activity as the Law defines priorities and conceptual decisions of planning and use of the territories of the country. According to the Law, the General Scheme of Planning of Territories of Ukraine is the basis for the development of all further urban planning documentation.

The logical conclusion of the first stage was the Decree of the Cabinet of Ministers of Ukraine № 536-r on July 18, 2007, which adopted the Concept of the Urban Planning Code of Ukraine (2). However, the Code was not adopted. In our view, this situation demonstrates that the legislator has the lack of a clear line and understanding in what way construction activity regulation in our country should be developed, since the main task is to systematize a large number of scattered provisions of urban planning legislation, which was failed to realize.

The second stage (2008-2010) was marked by the global financial crisis of 2008-2009, which significantly influenced the development of the construction industry. In this regard, the Verkhovna Rada of Ukraine adopted the Law of Ukraine «On Preventing the Impact of the Global Financial Crisis on the Development of the Construction Industry and Housing» (14). This Law defined possible ways of solving crisis situations in the building sphere and organizational actions to solve urgent problems in the sphere of housing construction. Its adoption became one of the factors that allowed the construction industry to reach the pre-crisis level of housing construction.

An important milestone in the development of legislation on construction activity was the adoption of the Law of Ukraine «On Amendments to Some Legislative Acts of Ukraine on Promoting Construction» dated 16.09.2008 (12), which didn't have its own importance but introduced a wide range of amendments to the basic legislative acts that regulated the complicated procedure of capital construction. Specifically, clear standards were set to determine the main constituents of the output for the design of an urban development object, and the acceptance for completion of construction works was envisaged on the basis of a conformity certificate.

The legislator did not ignore the problems associated with the technical regulation of construction activities. Thus, in 2009, the Verkhovna Rada adopted the Law of Ukraine «On Building Regulations» (5), which established the legal and organizational principles for the development, approval, registration and application of building provisions, and defined the building provisions as subordinate regulation of technical nature. 
In 2010, the Cabinet of Ministers of Ukraine approved the Concept of Implementation of the State Policy for Regulatory Support of Construction in Ukraine for the period up to 2015 (4) with the aim to develop a regulatory framework adapted to international requirements. In the following years, the revision of state standards in the sphere of construction, building provisions and rules of the former Soviet Union took place, and the number of standards harmonized with the standards of the European Union was succeeded.

The third stage (2011 - present) became a kind of «revolution» in the construction industry because its main purpose was to introduce changes that would allow the regulatory framework of the building industry to reach the level of the developed western countries. The first step was the adoption of the Law of Ukraine «On Regulation of Urban Development» (11), which came into force on February 23, 2011. The Law introduced significant changes to the permitting procedure in the implementation of construction, established the division of construction objects by categories of complexity.

This stage was characterized not only by the adoption of conceptually new regulations (though they are necessary), but by the improvement of existing ones. This, on the one hand, indicates that the established regulatory framework was imperfect, and on the other - it makes possible to state the readiness of the legislator to take further large-scale steps towards creating effective legal mechanisms for regulating the construction industry.

Some of the first changes occurred after the adoption of the Law of Ukraine «On Amendments to Certain Legislative Acts of Ukraine on Strengthening Accountability and Improvement of State Regulation in the Area of Urban Development» (12) dated 22.12.2011. According to these amendments the Law of Ukraine On Liability for Offenses in the Sphere of Urban Development expanded the range of entities that can be brought to responsibility and what is most important there is a clear differentiation of responsibility of the customer, the entity carrying out the design, performer of building activity.

The Cabinet of Ministers of Ukraine issued the Decree on 02.10.2013 «On Amendments to the Procedure for Imposing Fines for Offenses in the Sphere of Urban Planning» (3) to improve the efficiency of the state architectural and construction control and to make the process of imposing fines for offenses in the sphere of urban planning more accurate. An important innovation is the regulation of actions of the State Construction Inspectorate in case of refusal of the entity to receive documents confirming the violation of the law, since such cases were numerous, and due to the lack of their legislative regulation, the very procedure of imposing a fine was delayed.

In accordance with the Law of Ukraine «On Amendments to Certain Legislative Acts of Ukraine on Improvement of Urban Planning Activity» dated 17.01.2017 (13), 
another significant changes were made to the Law of Ukraine On Regulation of Urban Planning Activity. They canceled the assessment of the construction object by difficulty categories. Instead, according to the Law, a new concept was introduced the class of consequences of buildings and structures. The class of consequences is determined for each object - houses, buildings, structures of any purpose, their parts, linear objects of engineering and transport infrastructure.

In the third stage, new state building codes (DBN B. 2.2-12: 2018 «Territory Planning and Development») (1) came into force. It regulate the development of all urban and project documentation in Ukraine. Among the key points of the new DBN are following innovations: limiting the height of buildings in cities; building restrictions in green areas («green lines») which define the boundaries of landscaped and recreational areas where construction is prohibited.

Conclusion. Since declaration of independence, Ukraine has come a long way in its development, during which a number of important acts have been adopted. This allowed to form the legal basis for regulating building activity. At the same time, due to the integration and adaptation of the Ukrainian legislation to the European standards, the building legislation has been substantially changed, and the process of harmonization of regulations has not been completed. The main directions of development of the legal provision of building in Ukraine have been defined by the Concept of Realization of the State Policy on the Legal Support in Ukraine for the period until 2015, but the action plan has not been fully implemented and the new Concept has not yet been developed.

In our view, with the purpose to solve these problems, there should: 1) focus on the systematization of a large number of scattered provisions of urban planning legislation by developing and adopting a single codified act in the sphere of construction; 2) ensure acceleration of harmonization of Ukrainian regulations with European standards 3) to develop and adopt the Concept of Realization of the State Policy on Legal Support of Building in Ukraine.

\section{REFERENCES}

1. DBN B. 2.2-12: 2018 «Planuvannya i zabudova terytorii» [State building codes B. 2.2-12: 2018 «Territory Planning and Development»] (n.d.) dbn.co.ua Retrieved from https://dbn.co.ua/load/normativy/dbn/b_2_2_12/1-1-0-1802 [in Ukrainian].

2. Postanova Kabinetu Ministriv Ukrainy «Pro shvalennya Kontseptsii Mistobudivnogo kodeksu Ukrainy» № 536-p vid 18.07.2007 [Decree of the Cabinet of Ministers of Ukraine «On approval the Concept of the Urban Planning Code of Ukraine»] (n.d.) zakon.rada.gov.ua. Retrieved from https://zakon.rada.gov.ua/laws/ show/536-2007-p [in Ukrainian]. 
3. Postanova Kabinetu Ministriv Ukrainy «Pro vnesennya zmin do Poryadku nakladennya shtrafiv za pravoporushenna u sferi mistobuduvannya» № 735-2013-п vid 02.10.2013 [Decree of Cabinet of Ministers of Ukraine «On Amendments to the Procedure for Imposing Fines for Offenses in the Sphere of Urban Planning»] (n.d.) zakon.rada.gov.ua Retrieved from https://zakon.rada.gov.ua/laws/show/735-2013-п [in Ukrainian].

4. Rozporyadshennya Kabinetu Ministriv Ukrainu «Pro uhvalennya Kontseptsii realizatsii derzavnoi polityky z normatyvnoho zabezpechennya budivnytstva v Ukraini do 2015 rocu» № 1436-2010-p vid 14.07.2010 [Order of the Cabinet of Ministers of Ukraine «On approval Concept of Implementation of the State Policy for Regulatory Support of Construction in Ukraine for the period up to 2015»] (n.d.) zakon.rada.gov.ua. Retrieved from https://zakon.rada.gov.ua/laws/show/1436-2010-p [in Ukrainian].

5. Zakon Ukrainy «Pro budivelni normy» № 1704-VI vid 05.112009 [Law of Ukraine «On Building Regulations»] (n.d.) zakon.rada.gov.ua. Retrieved from https://zakon.rada.gov.ua/laws/show/1704-17/ed20091105 [in Ukrainian].

6. Zakon Ukrainy «Pro heneralnu shemu planuvannya terytoriy Ukrainy» № 3059-III vid 07.02.2002 [Law of Ukraine «On the General Scheme of Planning of the Territory of Ukraine»] (n.d.) zakon.rada.gov.ua. Retrieved from https://zakon.rada.gov.ua/laws/show/3059-14/ed20020207 [in Ukrainian].

7. Zakon Ukrainy «Pro osnovy mistobuduvannya» № 2780-XII vid 16.11 .1992 [Law of Ukraine «On the Basics of Urban Planning «]. (n.d.) zakon.rada.gov.ua. Retrieved from https://zakon.rada.gov.ua/laws/show/2780-12 [in Ukrainian].

8. Zakon Ukrainy «Pro planuvannya i zabudovu teritoriy» vid 20.04 .2000 [Law of Ukraine «On Planning and Development of Territories dated»]. (n.d.) zakon.rada.gov.ua. Retrieved from https://zakon.rada.gov.ua/laws/show/169914/ed20000420 [in Ukrainian].

9. Zakon Ukrainy «Pro rehuluvannya mistobudivnoi diyalnosti» 3038-VI vid 17.02.2011 [Law of Ukraine «On Regulation of Urban Development»] (n.d.) zakon.rada.gov.ua Retrieved from https://zakon.rada.gov.ua/laws/show/303817/ed20110217 [in Ukrainian].

10. Zakon Ukrainy «Pro vidpovidalnist pidpruemstv, ih obyednan, ustanov ta organizatsiy za pravoporushennya y sferi mistobuduvannya» vid 14.10.1994 [Law of Ukraine «On the Responsibility of Enterprises, their Associations, Institutions and Organizations for Offenses in the Sphere of Urban Development»]. (n.d.) zakon.rada.gov.ua Retrieved from https://zakon.rada.gov.ua/laws/show/208/94-вр [in Ukrainian].

11. Zakon Ukrainy «Pro vnesennya zmin do deyakyh zakonodavchuh aktiv Ukrainy shchodo spryyannya budivnutstvu» № 509-VI vid 16.09.2008 [Law of 
Ukraine «On Amendments to Some Legislative Acts of Ukraine on Promoting Construction»] (n.d.) zakon.rada.gov.ua. Retrieved from https://zakon.rada.gov.ua/ laws/show/509-17/ed20080916 [in Ukrainian].

12. Zakon Ukrainy «Pro vnesennya zmin do deyakyh zakonodavchyh aktiv Ukrainy shchodo posulennya vidpovidalnosti ta vdoskonalennya derzavnoho rehuluvannya u sferi mistobudivnoi diyalnosti» № 4220-VI vid 22.12.2011 [Law of Ukraine «On Amendments to Certain Legislative Acts of Ukraine on Strengthening Accountability and Improvement of State Regulation in the Area of Urban Development»] (n.d.) zakon.rada.gov.ua Retrieved from https://zakon.rada.gov.ua/ laws/show/4220-17/ed20111222 [in Ukrainian].

13. Zakon Ukrainy «Pro vnesennya zmin do deyakyh zakonodavchyh aktiv Ukrainy shchodo ydoskonalennya mistobudivnoi diyalnosti» № 1817-VIII vid 17.01.2017 [Law of Ukraine «On Amendments to Certain Legislative Acts of Ukraine on Improvement of Urban Planning Activity»] (n.d.) zakon.rada.gov.ua Retrieved from https://zakon.rada.gov.ua/laws/show/1817-19/ed20170117 [in Ukrainian].

14. Zakon Ukrainy «Pro zapobihannya vplyvu svitovoi finansovoi cryzy na rozvytok budivelnoi haluzi» № 800-VI vid 25.12.2008 [Law of Ukraine «On Preventing the Impact of the Global Financial Crisis on the Development of the Construction Industry and Housing»] (n.d.) zakon.rada.gov.ua. Retrieved from https://zakon.rada.gov.ua/laws/show/800-17/ed20081225 [in Ukrainian]. 